ENTREPRENEURSHIP AND SUSTAINABILITY ISSUES

ISSN 2345-0282 (online) http://jssidoi.org/jesi/

2020 Volume 8 Number 2 (December)

http://doi.org/10.9770/jesi.2020.8.2(19)
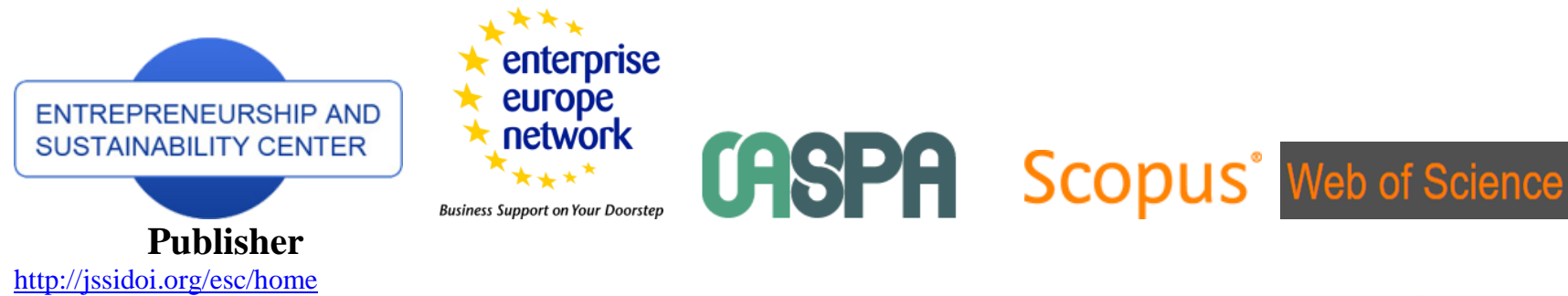

http://jssidoi.org/esc/home

Business Support on Your Doorstep

Clarivate

Analytics

\title{
THE ROLE OF FIRM'S MOBILE APPLICATIONS IN DEVELOPING BRAND'S EQUITY
}

\author{
Mohammad Fahmi Al-Zyoud \\ Al-Ahliyya Amman University, Business School, Marketing Departement Al-Saro, Al-Salt, Balqa Governorate, Amman, \\ Jordan \\ E-mail:m.alzyoud@ammanu.edu.jo
}

Received 15 December 2019; accepted 15 August 2020; published 30 December 2020

\begin{abstract}
With the appearance and wide spread of smart phones, individuals have become attached to their mobile phones in order to run their lives, it included texting, calling, calendar, GPS, and appointments. Organizations have exploited the use of smartphones in developing mobile applications in which a user can get the service of the organization and at the same time be exposed to all its marketing and promoting campaigns. Current study aimed at examining the influence of mobile applications on brand equity determinants (Brand Awareness, Perceived Quality, Brand Association and Brand Loyalty) from the perspective of mobile application users in Jordan. Results of study indicated that, mobile applications have a positive influence on brand equity and it managed to be a strong branding platform for marketers in general. In addition to that, results indicated that among the variables of brand equity, brand awareness was the most influenced by smartphones applications. Study recommended to carry out a research that examines the influence of mobile applications on health care performance and how can health care services be eased out for patients who don't have the ability to move from place to another like seniors and handicapped.
\end{abstract}

Keywords: smartphone applications; brand equity; mobile marketing; brand awareness; perceived quality; brand association; brand loyalty

Reference to this paper should be made as follows: Al-Zyoud, M.F. 2020. The role of firms`s mobile applications in developing brand`s equity. Entrepreneurship and Sustainability Issues, 8(2), 324-340. http://doi.org/10.9770/jesi.2020.8.2(19)

JEL Classifications: M15, M31, M37

\section{Introduction}

The use of cellphones and mobile phones has risen to be a main tool for marketing and promoting for services and goods, hence drawing colossal enthusiasm from both marketers and consumers.According to Masika (2013), mobile phone users presently remain at 6 billion all around the world. Ordinary phones shape the dominant part of these telephones while advanced mobile phones (smart phones) remain at around 1 billion. In this way, cell phones present the best chance of every connected device (Notebooks, desktops, mobile phones, tablets, and ultramobile Portable Computers) as an advertising stage. The Mobile telephone shows a few marketing correspondence tool including yet not restricted to Mobile inquiry, Mobile video, Mobile photos and Mobile informing. One road of versatile marketing that has gotten critical consideration is Mobile messaging through the 


\section{ENTREPRENEURSHIP AND SUSTAINABILITY ISSUES}

ISSN 2345-0282 (online) http://jssidoi.org/jesi/

2020 Volume 8 Number 2 (December)

http://doi.org/10.9770/jesi.2020.8.2(19)

short message service (SMS) marketing. SMS is an application that enables mobile users to send an instant message of up to 160 characters between cell phones. Sending short messages is likewise regularly known as "messaging" or "content informing". To date, SMS has turned into the most prevalent of every versatile application. In 2010, the quantity of instant messages sent all inclusive achieved 6.1 trillion, or around 600,000 instant messages are sent each second Masika (2013). From the part of business, an ongoing review found that the level of mobile users in European nations who got SMS ad in 2007 moved toward about $100 \%$.

\section{Literature Review}

A mobile application - generally referred to as APP - is a computerized software that designed to be used using a smart phone or a tablet. Those applications are normally used in order to get the same service that can be reached through using them on PCs. The idea of mobile application is now becoming more and more apparent given that the number of people using smart phones is increasing on daily bases (King and Raja, 2012).

Lee et al. (2004) argues that a mobile app can be referred to as a software program created for cell phones, for example, cell phones and tablets. They transform cell phones into small-scale powerhouses of capacity and fun. A few gadgets come preloaded with some versatile applications cordiality of their producers or the portable specialist organizations with which they are related (for instance, Verizon, AT\&T, T-Mobile, and so on.), yet numerous more applications are accessible through gadget particular application stores (Schierz et al., 2010). Washburn (2011) states that the reasons for these applications run the array, from utility, efficiency, and route to stimulation, games, wellness, and pretty much any others possible. Internet based life is a standout amongst the most prevalent fields of versatile application improvement and reception. Actually, Facebook was the most broadly utilized application in 2017 over all stages.

Numerous online substances have both versatile sites and portable applications (Pavlovaite, and Griesiene, (2019). All in all, the distinction lies in reason: An application is generally littler in scope than a portable site, offers greater intuitiveness, and displays more particular data in a configuration that is simple and natural to use on a cell phone. A versatile application designer makes an application particularly for the working framework in which it will run. For instance, versatile applications for the iPad are bolstered by Apple's iOS, yet not Google's Android. An Apple application cannot keep running on an Android telephone, and the other way around. Frequently, designers make a variant for each; for instance, a versatile application in the Apple Store may have a partner in Google Play (Rubin et al., 2015).

Mobile applications appreciate relatively lasting network also, the capacity to trade data with their own particular backend also, other outsider servers. This paper demonstrates that much of this correspondence does not convey any unmistakable incentive to the application's client: incapacitating it leaves the conveyed application encounter totally unblemished. However, this secretive correspondence accompanies costs, for example, potential security breaks, transfer speed charges, control utilization on the gadget, and the unsuspected nearness of proceeded with correspondence between the gadget and remote associations. Truth be told, we saw that a few prevalent applications, e.g., Walmart and Twitter, produce administrations that secretively speak with remote servers even at the point when the application itself is latent and the client is unconscious that the brought forth benefits are running out of sight (Priyantha et al., 2001). According to Florido-Benítez and Martínez (2015), mobile applications are by and large progressively utilized in cell phones and tablets to get to news, amusements, excitement, climate and other data. Extensive airplane terminals are exploiting the solidification of cell phones in the 21 st century to make applications for marking and correspondence. These applications have prompted the production of another promoting outlet, portable marketing, that can be utilized as a business specialized instrument. Over the most recent couple of years, this advertising model has united itself into an item as opposed to a simple correspondence instrument because of its multi usefulness, which contributes increased the value of the substance of the administrations advertised. Portable marketing likewise adds to larger amounts of fulfillment 


\section{ENTREPRENEURSHIP AND SUSTAINABILITY ISSUES}

ISSN 2345-0282 (online) http://jssidoi.org/jesi/ 2020 Volume 8 Number 2 (December) http://doi.org/10.9770/jesi.2020.8.2(19)

among airplane terminal customers. In any case, for versatile marketing foundation to make long haul progress, it must give advantages to air terminals and carriers through the portable applications. New data innovations made new media - cell phones, by which can be applied mobile marketing. In his paper, Joshi (2013) distinguishes cell phones as a critical development whose effect on the organization most likely will not stop soon. To accentuate their significance and vital part in business, Joshi (2013) calls cell phones "vital development". Since cell phones are in every case near their proprietors, they make enthusiastic effect. Dushinski (2009) in his paper characterizes mobile marketing as a progressive device for associating organizations with every one of their customers through their cell phones in the ideal time, on a correct place and with proper direct message. Becker and Arnold (2010) stress meaning of mobile marketing which have been given from Mobile Marketing Association, which says that mobile marketing is an arrangement of methods that empowers correspondence with organizations target gathering of people on intuitive and applicable way through cell phones. Likewise, mobile marketing is another marketing channel, which has been made amid the advancement of online business. In spite of the fact that it is conceivable to connect target bunches by means of cell phones, Tanakinjal et al. (2011) express that it is critical to attempt and investigate the conceivable outcomes to influence it to work. As indicated by Andrews et al. (2012), portable promoting is any type of marketing correspondence that has been utilizing cell phones amid the making of potential chances and advantages for clients, what incorporates area based versatile administrations and administrations for the conveyance of portable substance. Advertising specialists concur with the way that exercises that have been going ahead with the cell phones, in the most recent decade, had a huge influence on mobile marketing and on plan for buy of potential clients later on (Chinomona I Sandada, 2013). The same number of individuals compare the term of advertising with advancement, it likewise occurs with the term of portable marketing and versatile advancement, what is without a doubt off-base. Tanakinjal et al. (2011) clarify the distinction between these two terms. Versatile marketing is a driver and an establishment for the trading of substance and direct reaction, while portable promoting is type of a message, which has been sent by means of cell phone. Mobile marketing is a type of correspondence with existing and potential customers. Premise of this correspondence has been improvement of media transmission, data and remote advancements. Mobile marketing does not lose the feeling of advertising but rather mirrors the inventiveness of marketing experts and their technique while result ought to be subjective and fruitful advertising correspondence between the organization and clients. Henceforth, versatile advancement is a piece of portable marketing and is one of its most critical exercises. Cell phones are claimed by one individual what empowers correspondence with a particular individual and message that has been sent to them is promptly accessible Hazlett (2011). Likewise, connection with the customers can be entirely unexpected for every customer, what is not the situation in different sorts of advertising (Dushinski, 2009). Due to the open doors given by versatile marketing, organizations can without much of a stretch incorporate into the trading of data with existing and potential clients, with the point of enhancing items. Organizations are progressively settling on portable promoting in view of the pattern and its hopeful projections (Smith, 2010).

\section{Brand Equity}

Brand equity is one of the most important aspects in marketing management. The term brand equity was brought into light by Farguhar (1989) who stated that brand equity has the ability to bring about an added value to the product. Keller (1993, p. 1) defined brand equity as "the differential effect of brand knowledge on consumer response to the marketing of the brand", Pullig (2008, p.1) on the other hand defined brand equity as "the value of the brand in the market place". Also, Severi and Ling (2013, p.125) defined brand equity as "the marketing and financial values linked with a brand's strength in the market, including actual proprietary brand assets, brand name awareness, brand loyalty, perceived brand quality, and brand associations".

According to Severi and Ling (2013) high brand value, a brand with high appreciations and acceptance, it implies that the brand can make a type of positive differential reaction in the commercial center. This can imply that your image is effortlessly conspicuous when experienced in promoting or seen on a yard sign. It can imply that your 


\section{ENTREPRENEURSHIP AND SUSTAINABILITY ISSUES}

ISSN 2345-0282 (online) http://jssidoi.org/jesi/

2020 Volume 8 Number 2 (December)

http://doi.org/10.9770/jesi.2020.8.2(19)

image is one of the initial ones reviewed when a pertinent incite is utilized - "who might I call to talk about posting my home?" It could imply that people would pay a superior cost for your brand's putting forth. On account of a land exchange, people would pay a standard commission and feel as though they got an important great administration from an outstanding and confided in mark. It could imply that when somebody requests a referral, your image is the first that is prescribed to others. These are certain reactions to the brand - a promptly conspicuous brand, a brand that is reviewed rapidly and effortlessly when required, one that people will pay a top notch cost to gain, and a brand that is prescribed to others. These are on the whole attributes of a high value mark (Simon and Sullivan, 1993).On the other hand, Wood (2000) states that an attempt to characterize the connection amongst clients and brands created the term "brand equity" in the advertising literature. The idea of brand equity has been discussed both in the literature related to branding and marketing, and has featured the significance of having a long haul center inside brand management. Despite the fact that there have been critical moves by organizations to be key in how marks are dealt with, an absence of normal wording and theory inside and between disciplines perseveres and may impede correspondence. Brand equity, similar to the ideas of brand and included value has multiplied into different implications. Researchers have a tendency to characterize brand equity uniquely in contrast to advertisers, with the idea being characterized both as far as the connection amongst client and brand (customer arranged definitions), or as something that accumulates to the brand proprietor (organization situated definitions). Severi and Ling (2013) improves the assortment of methodologies, by giving an order of the distinctive implications of brand equity as: the aggregate estimation of a brand as a detachable resource when it is sold, or included on an accounting report; a proportion of the quality of customers' connection to a brand; a portrayal of the affiliations and convictions the buyer has about the brand. Piaralal and Mei (2015) noted that the term brand equity id constructed from multiple dimensions, which forms its meaning and influence. Those dimensions are:

\section{Brand Awareness}

According to Severi and Ling (2013, p.126) brand awareness is one of the most important dimensions of brand equity, and it refers to the "durability of the brand that embedded in the customer memory".Djerv and Malla (2012, p.9) stated that brand awareness is the "brand's ability to be recognized or recalled as a member of a certain product category or service". It is believed, that brand awareness plays a significant role in the process of decision making process within the clients due to the fact that it helps the brand being remembered in the mindset of the client specifically if they were the type of people who build their purchase decision based on brand, also it helps in forming the strength of the brand leading to greater loyalty and association (Awan and Rehman, 2014; Piaralal and Mei, 2015; Hashem, 2016).

\section{Perceived Quality}

The perceived quality is the element that determents the brand equity as appeared by Severi and Ling (2013). The authors defined perceived quality as "the overall perception of customers about brilliance and quality of products or services in comparing with the rivalry offering" (p.127). It is worth to mention here that the perceived quality differs from the quality of the product; perceived quality refers to the customer's emotional evaluation of the product, which can be unfair to use as a general evaluation of the product itself given that the emotional evaluation differs from a customer to another. In addition to that, perceived quality is considered to be a key factor in influencing the customer's decision-making process to purchase (Sprosen, 2014).

\section{Brand Association}

Low and Lamb (2000) defined brand association as the memorable characteristics, specifications and ideas that are memorable in the customers' mindset. Brand association can also refer to the set of items, description that makes the brand memorable for others (Gordon et al., 2016; French and Smith, 2013). 


\section{Brand Loyalty}

This dimension is the core of the concept of brand equity as stated by Djerv and Malla (2012). If the customers buy the item just for its price, features or convenience, and without any interest in the name of the brand then the equity is very weak. On the other hand, if the customer buys a product for the brand, which - from customers' perspective - guarantees for them quality, convenience, good features and suitable prices then the equity is high. Generally speaking, customers who do not get what they paid for are usually customers without loyalty for the brand, and they are welling to change their mindset into another brand. In the case of loyalty, the prior experience of a customer is a must, a customer cannot be considered loyal or not if they haven't had the needed prior experience of the brand (Piaralal and Mei, 2015).

\section{Aims}

From the above argument, it can be seen that using mobile phones in marketing has become a main tool for marketers and organization launching from the fact that individuals are becoming attached to their mobiles. They manage a lot of stuff using mobiles this includes emails, calendars, appointments, games, texting and GPS. From that point, marketers have exploited that idea of being attached to mobiles and has worked on making it the main and most important marketing platforms on which a marketer guarantees the receiving of the marketing initiative to the users. With the wide spread use of smart phones, and the appearance of mobile applications marketers have also benefited from this concept through building an application that is able to give the service to the clients along with the marketing process. Many large corporations now have its own mobile application which using it from the client is almost as effective as visiting the organization itself or one of its service booths. That way, clients find that this process saves them time and efforts and at the same time increases the percentage of users and opens the gates wider for potential clients. Launching from a study by (Masika, 2013; Sprosen, 2014; Vikström and Zheng, 2013; Tetere, 2011) this study aimed at examining the influence of using mobile application in increasing the brand equity from the perspective of mobile applications users in Jordan.

Based on the aim above, current study determined on answering the following questions: How can mobile applications help in developing brand equity?

In order to answer the above questions, following model was built so as to determine the main hypotheses of study (Figure 1):

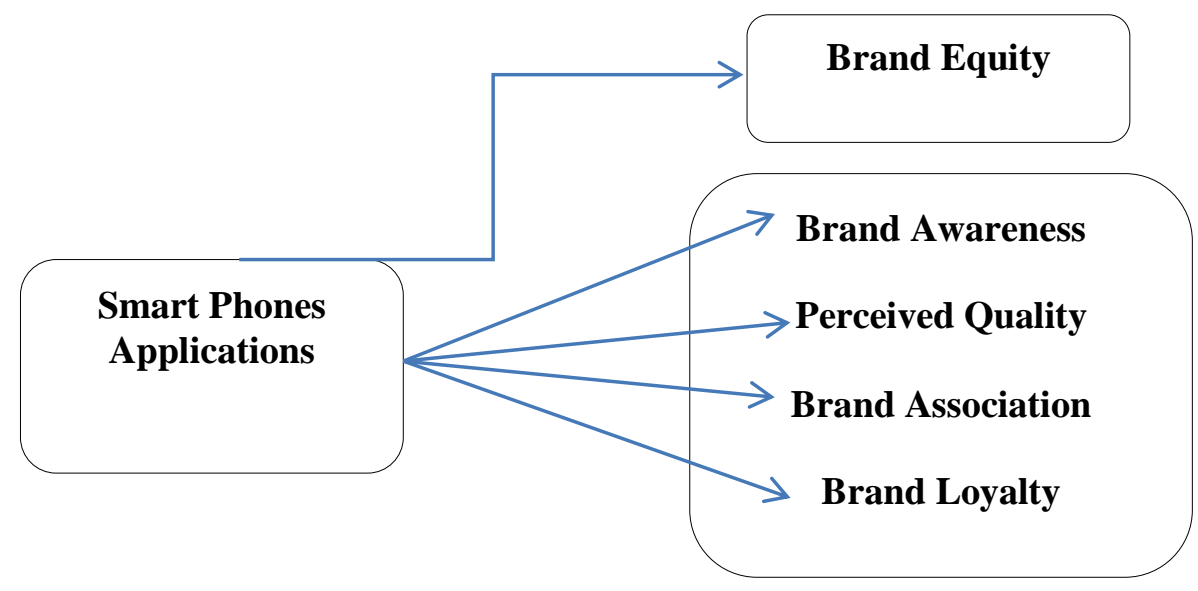

Figure 1. Study Model (Gunawardane et al., 2016; Masika, 2013; Trillo, 2017) 
Based on the presented model above, the hypotheses of study will be the following:

Main Hypothesis:

$\mathbf{H}_{1}$ : Mobile applications have a statistically significant influence on brand equity from the perspective of smartphones users in Jordan

Sub-Hypotheses:

$\mathbf{H}_{\mathbf{1}}$ : Mobile applications have a statistically significant influence on brand awareness from the perspective of smartphones users in Jordan

$\mathbf{H}_{1 \mathrm{~b}}$ : Mobile applications have a statistically significant influence on perceived quality from the perspective of smartphones users in Jordan

$\mathbf{H}_{1 \mathbf{c}}$ : Mobile applications have a statistically significant influence on brand association from the perspective of smartphones users in Jordan

$\mathbf{H}_{1 \mathrm{~d}}$ : Mobile applications have a statistically significant influence on brand loyalty from the perspective of smartphones users in Jordan

\section{Methods}

\section{Methodological Approach}

In order to answer study questions and process the hypotheses of current study the author has chosen the quantitative approach. This approach gives a chance to researchers to apply their study on large numbers of individuals in order to get more dependable results which cover a large number of participants.

Tool of Study

The researcher developed a self-administered questionnaire which was distributed on the study sample in order to collect data. The questionnaire consisted of two main parts, the first took into perspective the demographic variables including (gender, age, education) while the other part consisted to statements regarding the study variables of brand equity and mobile applications in smartphones.

\section{Population and Sample}

The population of the study was formed of Jordanian consumers who use smartphones applications. The initial sample consisted of (700) individuals from malls, retail stores and commercial complexes in the Jordanian capital, Amman. The researcher was able to retrieve (520) properly filled questionnaires for analysis. The response rate of current study reached $74.2 \%$ which is a statistically approved rate.

\section{Results}

The empirical data obtained in the process of the research is explained in this section, figures, tables, graphs are used to facilitate such. In this results section we will examine demographic, sample, questionnaire analysis, hypothesis testing, and reliability testing. 
Table 1. Sample characteristics according to gender

\begin{tabular}{|l|l|r|r|r|r|}
\hline \multicolumn{2}{|c|}{} & Frequency & Percent & Valid Percent & Cumulative Percent \\
\hline \multirow{3}{*}{ Valid } & Male & 285 & 54.8 & 54.8 & 54.8 \\
\cline { 2 - 6 } & Female & 235 & 45.2 & 45.2 & 100.0 \\
\cline { 2 - 6 } & Total & 520 & 100.0 & 100.0 & \\
\hline
\end{tabular}

Table (1) highlighted the sample characteristics according to gender. It appeared through the analysis that 54.8\% of individuals were males, while $45.2 \%$ of individuals appeared to be females. This indicates that males are into using mobile applications compared to females.

Table 2. Sample characteristics according to age

\begin{tabular}{|c|c|r|r|r|r|}
\hline \multicolumn{2}{|c|}{} & Frequency & Percent & Valid Percent & Cumulative Percent \\
\hline \multirow{3}{*}{ Valid } & $18-22$ & 79 & 15.2 & 15.2 & 15.2 \\
\cline { 2 - 6 } & $23-27$ & 193 & 37.1 & 37.1 & 52.3 \\
\cline { 2 - 6 } & $28-32$ & 161 & 31.0 & 31.0 & 83.3 \\
\cline { 2 - 6 } & +33 & 87 & 16.7 & 16.7 & 100.0 \\
\cline { 2 - 6 } & Total & 520 & 100.0 & 100.0 & \\
\hline
\end{tabular}

Table (2) presented the sample characteristics according to age. From the analysis, it appeared that the majority of the sample $37.1 \%$ was from the age range of (23-27) years old.In the $2^{\text {nd }}$ rank came individuals within the age range of $28-32$ years old forming $31 \%$ of the total sample.

Table 3. Sample characteristics according to education

\begin{tabular}{|c|c|r|r|r|r|}
\hline \multicolumn{2}{|c|}{} & Frequency & Percent & Valid Percent & Cumulative Percent \\
\hline \multirow{3}{*}{ Valid } & BA & 48 & 9.2 & 9.2 & 9.2 \\
\cline { 2 - 6 } & MA & 352 & 67.7 & 67.7 & 76.9 \\
\cline { 2 - 6 } & PhD & 120 & 23.1 & 23.1 & 100.0 \\
\cline { 2 - 6 } & Total & 520 & 100.0 & 100.0 & \\
\hline
\end{tabular}

Table (3) presented the sample characteristics according to education. It appeared that the majority if the sample $67.7 \%$ held master degree compared to $23.1 \%$ who held $\mathrm{PhD}$ degree. 
Table 4. Sample characteristics according to income

\begin{tabular}{|l|l|r|r|r|r|}
\hline \multicolumn{2}{|c|}{} & Frequency & Percent & Valid Percent & Cumulative Percent \\
\hline \multirow{3}{*}{ Valid } & $250-500$ & 114 & 21.9 & 21.9 & 21.9 \\
\cline { 2 - 6 } & $501-750$ & 84 & 16.2 & 16.2 & 38.1 \\
\cline { 2 - 6 } & $751-1000$ & 79 & 15.2 & 15.2 & 53.3 \\
\cline { 2 - 6 } & $1001-1250$ & 111 & 21.3 & 21.3 & 74.6 \\
\cline { 2 - 6 } & $1251+$ & 132 & 25.4 & 25.4 & 100.0 \\
\cline { 2 - 6 } & Total & 520 & 100.0 & 100.0 & \\
\hline
\end{tabular}

Table (4) above described sample characteristics according to income, from the analysis, it appeared that the majority of the sample (25.4\%) had an income range of +1251 JOD which is explained through the fact that most brands which builds its own applications are mostly above average when it comes to price.

\section{Questionnaire Analysis}

Table 5. Descriptive Statistics

\begin{tabular}{|c|c|c|c|c|c|}
\hline \multicolumn{6}{|l|}{$\begin{array}{ll}\text { Smartphones Applications } \\
\end{array}$} \\
\hline $\begin{array}{l}\text { Smartphones application interacts with consumers and present the best } \\
\text { service for them }\end{array}$ & 520 & 1.0 & 5.0 & 3.877 & .8846 \\
\hline $\begin{array}{l}\text { Using my phone to get a service is much easier than visiting the company } \\
\text { branch }\end{array}$ & 520 & 1.0 & 5.0 & 3.860 & .8918 \\
\hline $\begin{array}{l}\text { I know about the promotions and adds from the app not the main website of } \\
\text { the brand }\end{array}$ & 520 & 1.0 & 5.0 & 3.727 & .9847 \\
\hline $\begin{array}{l}\text { I always depend on the application on my phone to know the latest } \\
\text { promotions }\end{array}$ & 520 & 1.0 & 5.0 & 3.569 & 1.0177 \\
\hline I have applications to all my favorite brands on my phone & 520 & 1.0 & 5.0 & 3.567 & .9472 \\
\hline \multicolumn{6}{|c|}{ Brand Awareness } \\
\hline I always follow my favorite brand on its application & 520 & 1.0 & 5.0 & 3.573 & 1.0079 \\
\hline Weak brands don't have mobile application & 520 & 1.0 & 5.0 & 3.458 & 1.0360 \\
\hline When there is an application I assume it is a powerful brand & 520 & 1.0 & 5.0 & 3.540 & .9866 \\
\hline I know the application of a certain brand as soon as I see its logo & 520 & 1.0 & 5.0 & 3.508 & .9696 \\
\hline \multicolumn{6}{|c|}{ Perceived Quality } \\
\hline Good brands always have applications & 520 & 1.0 & 5.0 & 3.617 & .9545 \\
\hline
\end{tabular}


ISSN 2345-0282 (online) http://jssidoi.org/jesi/ 2020 Volume 8 Number 2 (December) http://doi.org/10.9770/jesi.2020.8.2(19)

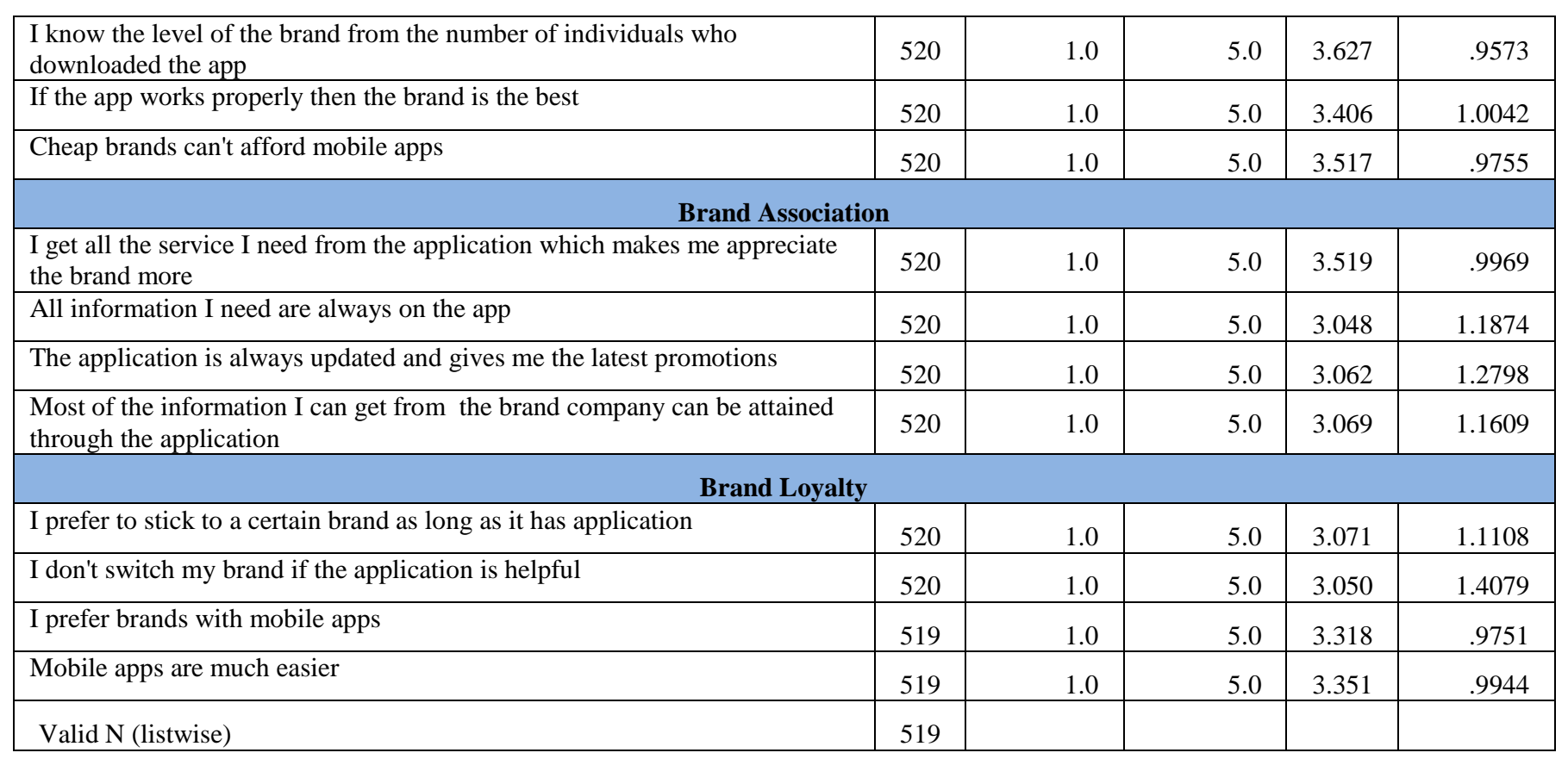

According to table (5), it was seen that all of the questionnaire statements were positively received by the sample which was noted through their answers on the scale. The means of the statements scored higher than 3.00, which were seen to be a good indicator. This gives an indication that the sample individuals had a positive attitude towards statements of the questionnaire referring to the variables as positively received.

Table 6. Descriptive Statistics of Variables

\begin{tabular}{|l|c|r|r|r|r|}
\hline & $\mathrm{N}$ & Minimum & Maximum & Mean & Std. Deviation \\
\hline Smartphone applications & 520 & 1.29 & 5.00 & 3.6953 & .77397 \\
\hline Brand Awareness & 520 & 1.00 & 5.00 & 3.5197 & .84390 \\
\hline Brand Quality & 520 & 1.00 & 5.00 & 3.5418 & .82926 \\
\hline Brand Association & 520 & 1.00 & 5.00 & 3.1745 & .97027 \\
\hline Brand Loyalty & 520 & 1.00 & 5.00 & 3.1952 & .88139 \\
\hline Brand Equity & 520 & 1.13 & 5.00 & 3.3584 & .77014 \\
\hline
\end{tabular}

It appeared from table (6) above that sample individuals had positive attitude toward variables of study. It is shown in the table that all variables scored higher than 3.00 as a mean, which a statistically accepted results and a good indicator of positive attitudes.

\section{Reliability Test:}

Through employing Cronbachs' alpha, a reliability test was carried out. Results of the reliability test indicated that all of the items scored higher than the value of (0.60) and they all have given the value of (0.953). This refers to the tool consistency of the study. 


\section{Hypotheses Testing}

Main Hypothesis Testing (see Tables 7, 8, 9):

* $\quad \mathbf{H}_{1}$ : Mobile applications have a statistically significant influence on brand equity from the perspective of smartphones users in Jordan

Table 7. Model Summary H1

\begin{tabular}{|l|c|r|r|r|}
\hline Model & $\mathrm{R}$ & R Square & Adjusted R Square & Std. Error of the Estimate \\
\hline 1 & $.758^{\mathrm{a}}$ & .575 & .574 & .50267 \\
\hline
\end{tabular}

Table 8. ANOVA $^{\mathrm{a}} \mathrm{H} 1$

\begin{tabular}{|c|l|r|r|r|r|r|}
\hline \multicolumn{2}{|c|}{ Model } & Sum of Squares & \multicolumn{1}{c|}{ df } & Mean Square & F & Sig. \\
\hline \multirow{2}{*}{1} & Regression & 176.945 & 1 & 176.945 & 700.290 & $.000^{\mathrm{b}}$ \\
\cline { 2 - 7 } & Residual & 130.885 & 518 & .253 & & \\
\cline { 2 - 7 } & Total & 307.829 & 519 & & & \\
\hline
\end{tabular}

Table 9. Coefficients ${ }^{\mathrm{a}} \mathrm{H} 1$

\begin{tabular}{|c|c|c|c|c|c|c|}
\hline \multicolumn{2}{|c|}{ Model } & \multicolumn{2}{|c|}{ Unstandardized Coefficients } & \multirow{2}{*}{$\begin{array}{c}\text { Standardized Coefficients } \\
\text { Beta } \\
\end{array}$} & \multirow[t]{2}{*}{$\mathrm{t}$} & \multirow[t]{2}{*}{ Sig. } \\
\hline & & $\mathrm{B}$ & Std. Error & & & \\
\hline \multirow[t]{2}{*}{1} & (Constant) & .571 & .108 & & 5.302 & .000 \\
\hline & smart & .754 & .029 & .758 & 26.463 & .000 \\
\hline
\end{tabular}

The main hypothesis (H1) was tested through multiple regression. Results indicated that $\mathrm{R}$ value reached (0.758) and the variables are correlated. With a $\mathrm{T}$ value of 26.463 at level 0.05 it can be said that results approved the influence of smartphones applications on brand equity.

Sub-Hypotheses Testing (see Tables 10, 11, 12):

- $\mathbf{H}_{1 \mathrm{a}}$ : Mobile applications have a statistically significant influence on brand awareness from the perspective of smartphones users in Jordan

Table 10. Model Summary $\mathrm{H}_{1 \mathrm{a}}$

\begin{tabular}{|l|c|r|r|r|}
\hline Model & \multicolumn{1}{|c|}{$\mathrm{R}$} & R Square & Adjusted R Square & Std. Error of the Estimate \\
\hline 1 & $.789^{\mathrm{a}}$ & .622 & .621 & .51948 \\
\hline
\end{tabular}


Table 11. ANOVA ${ }^{a} \mathrm{H}_{1 \mathrm{a}}$

\begin{tabular}{|c|l|r|r|r|r|r|}
\hline \multicolumn{2}{|l|}{ Model } & Sum of Squares & \multicolumn{1}{c|}{ df } & Mean Square & F & Sig. \\
\hline \multirow{2}{*}{1} & Regression & 229.821 & 1 & 229.821 & 851.616 & $.000^{\mathrm{b}}$ \\
\cline { 2 - 7 } & Residual & 139.790 & 518 & .270 & & \\
\cline { 2 - 7 } & Total & 369.610 & 519 & & & \\
\hline
\end{tabular}

Table 12. Coefficients ${ }^{\mathrm{a}} \mathrm{H}_{1 \mathrm{a}}$

\begin{tabular}{|c|c|c|c|c|c|c|}
\hline \multicolumn{2}{|c|}{ Model } & \multicolumn{2}{|c|}{ Unstandardized Coefficients } & \multirow{2}{*}{$\begin{array}{c}\text { Standardized Coefficients } \\
\text { Beta }\end{array}$} & \multirow[t]{2}{*}{$\mathrm{t}$} & \multirow[t]{2}{*}{ Sig. } \\
\hline & & $\mathrm{B}$ & Std. Error & & & \\
\hline \multirow[t]{2}{*}{1} & (Constant) & .343 & .111 & & 3.080 & .002 \\
\hline & smart & .860 & .029 & .789 & 29.182 & .000 \\
\hline
\end{tabular}

Looking at tables $(10,11$, and 12$)$ it can be seen that the $1^{\text {st }}$ sub-hypothesis was tested through multiple regression. From the analysis it appeared that $\mathrm{R}$ value scored 0.789 and both variables were strongly correlated. In addition to that, the T value scored 29.182 at level 0.05 which accepts the hypothesis that smartphone applications positively influence brand awareness.

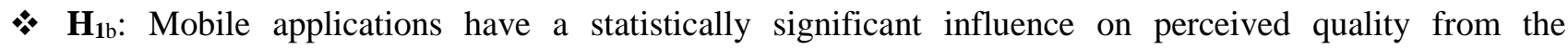
perspective of smartphones users in Jordan

Table 13. Model Summary $\mathrm{H}_{1 \mathrm{~b}}$

\begin{tabular}{|l|c|r|r|r|}
\hline \multicolumn{4}{|c|}{ Model Summary } \\
\hline Model & \multicolumn{1}{|c|}{ R } & R Square & Adjusted R Square & Std. Error of the Estimate \\
\hline 1 & $.684^{\mathrm{a}}$ & .468 & .467 & .60519 \\
\hline
\end{tabular}

Table 14. ANOVA ${ }^{\mathrm{a}} \mathrm{H}_{1 b}$

\begin{tabular}{|c|l|r|r|r|r|l|}
\hline \multicolumn{2}{|c|}{ Model } & Sum of Squares & \multicolumn{1}{c|}{ df } & Mean Square & F & Sig. \\
\hline \multirow{2}{*}{1} & Regression & 167.184 & 1 & 167.184 & 456.471 & $.000^{\mathrm{b}}$ \\
\cline { 2 - 7 } & Residual & 189.719 & 518 & .366 & & \\
\cline { 2 - 7 } & Total & 356.903 & 519 & & & \\
\hline
\end{tabular}

Table 15. Coefficients ${ }^{\mathrm{a}} \mathrm{H}_{1 b}$

\begin{tabular}{|c|c|c|c|c|c|c|}
\hline \multirow{2}{*}{\multicolumn{2}{|c|}{ Model }} & \multicolumn{2}{|c|}{ Unstandardized Coefficients } & \multirow{2}{*}{$\begin{array}{c}\text { Standardized Coefficients } \\
\text { Beta }\end{array}$} & \multirow[t]{2}{*}{$\mathrm{t}$} & \multirow[t]{2}{*}{ Sig. } \\
\hline & & $\mathrm{B}$ & Std. Error & & & \\
\hline \multirow[t]{2}{*}{1} & (Constant) & .832 & .130 & & 6.421 & .000 \\
\hline & smart & .733 & .034 & .684 & 21.365 & .000 \\
\hline
\end{tabular}


From testing hypothesis $1 \mathrm{~b}$, it can be seen that multiple regression scored an $\mathrm{R}$ value of 0.684 confirming the correlation between the variables. With a $\mathrm{T}$ value of 21.365 on level 0.05 it can be said that smartphones applications positively influences perceived quality of the brand (Tables 13, 14, 15).

* H1c: Mobile applications have a statistically significant influence on brand association from the perspective of smartphones users in Jordan

Table 16. Model Summary $\mathrm{H}_{1 \mathrm{c}}$

\begin{tabular}{|l|c|r|r|r|}
\hline Model & \multicolumn{1}{|c|}{$\mathrm{R}$} & R Square & Adjusted R Square & Std. Error of the Estimate \\
\hline 1 & $.618^{\mathrm{a}}$ & .382 & .381 & .76326 \\
\hline
\end{tabular}

Table 17. ANOVA ${ }^{\mathrm{a}} \mathrm{H}_{1 \mathrm{c}}$

\begin{tabular}{|c|l|r|r|r|r|l|}
\hline \multicolumn{2}{|c|}{ Model } & Sum of Squares & \multicolumn{1}{c|}{ df } & Mean Square & F & Sig. \\
\hline \multirow{2}{*}{1} & Regression & 186.828 & 1 & 186.828 & 320.696 & $.000^{\mathrm{b}}$ \\
\cline { 2 - 7 } & Residual & 301.772 & 518 & .583 & & \\
\cline { 2 - 7 } & Total & 488.600 & 519 & & & \\
\hline
\end{tabular}

Table 18. Coefficients ${ }^{\mathrm{a}} \mathrm{H}_{1 \mathrm{c}}$

\begin{tabular}{|c|c|c|c|c|c|c|}
\hline \multicolumn{2}{|c|}{ Model } & \multicolumn{2}{|c|}{ Unstandardized Coefficients } & \multirow{3}{*}{$\begin{array}{c}\text { Standardized Coefficients } \\
\text { Beta } \\
\end{array}$} & \multirow{3}{*}{$\begin{array}{c}\mathrm{t} \\
1.896 \\
\end{array}$} & \multirow{3}{*}{$\begin{array}{l}\text { Sig. } \\
.058 \\
\end{array}$} \\
\hline & & $\mathrm{B}$ & Std. Error & & & \\
\hline \multirow[t]{2}{*}{1} & (Constant) & .310 & .163 & & & \\
\hline & smart & .775 & .043 & .618 & 17.908 & .000 \\
\hline
\end{tabular}

In tables $(16,17,18)$ it appeared that through multiple regression the hypothesis scored an $\mathrm{R}$ value of 0.618 which confirmed the correlation of the variables. In addition to that, a value of T appeared to be 17.908 at level 0.05 which accepted the hypothesis indicating the existence of a positive influence of smartphone applications on brand association.

* Hobile applications have a statistically significant influence on brand loyalty from the perspective of smartphones users in Jordan

Table 19. Model Summary $\mathrm{H}_{1 \mathrm{~d}}$

\begin{tabular}{|l|c|r|r|r|}
\hline Model & $\mathrm{R}$ & R Square & Adjusted R Square & Std. Error of the Estimate \\
\hline 1 & $.569^{\mathrm{a}}$ & .324 & .323 & .72543 \\
\hline
\end{tabular}

Table 20. ANOVA ${ }^{\mathrm{a}} \mathrm{H}_{1 \mathrm{~d}}$

\begin{tabular}{|l|l|r|r|r|r|l|}
\hline \multicolumn{2}{|l|}{ Model } & Sum of Squares & \multicolumn{1}{c|}{ df } & Mean Square & F & \multicolumn{1}{c|}{ Sig. } \\
\hline \multirow{2}{*}{1} & Regression & 130.592 & 1 & 130.592 & 248.158 & $.000^{\mathrm{b}}$ \\
\cline { 2 - 7 } & Residual & 272.596 & 518 & .526 & & \\
\cline { 2 - 7 } & Total & 403.188 & 519 & & & \\
\hline
\end{tabular}


ENTREPRENEURSHIP AND SUSTAINABILITY ISSUES

ISSN 2345-0282 (online) http://jssidoi.org/jesi/

2020 Volume 8 Number 2 (December)

http://doi.org/10.9770/jesi.2020.8.2(19)

Table 21. Coefficients ${ }^{\mathrm{a}} \mathrm{H}_{1 \mathrm{~d}}$

\begin{tabular}{|l|l|r|r|r|r|r|}
\hline \multicolumn{2}{|l|}{ Model } & \multicolumn{2}{|c|}{ Unstandardized Coefficients } & Standardized Coefficients & \multirow{2}{*}{$\mathrm{t}$} & \multirow{2}{*}{ Sig. } \\
\cline { 3 - 8 } \multicolumn{2}{|l|}{} & B & Std. Error & Beta & & \\
\hline \multirow{2}{*}{1} & (Constant) & .800 & .155 & & 5.152 & .000 \\
\cline { 2 - 8 } & smart & .648 & .041 & .569 & 15.753 & .000 \\
\hline
\end{tabular}

The last hypothesis was tested through multiple regression and scored an $\mathrm{R}$ value of 0.569 . Also, the $\mathrm{T}$ value appeared to be 15.753 on level 0.05 which confirmed the correlation between the two variables and accepted the fact that smartphone applications positively influence brand loyalty.

\section{Discussion}

After reviewing results of study data analysis, the findings can be summed up as following:

1- Males appeared to be more into engaging in using mobile applications compared to females

2- The majority of sample was from the age range of 23-27 years old

3- The majority of the sample individuals held master degree

4- The majority of sample participants enjoyed the income of more than 1250 JOD which explains their interest in mobile applications and branding

5- The most influences variable of brand equity by mobile applications appeared to be the variable of awareness.

This explains the influence of mobile application in giving higher brand equity to the brand itself through raising the awareness of individuals towards a certain brand.

According to the results above, the researcher was able to answer the question of the study and proved that mobile applications as a marketing tool can be helpful in developing the brand equity among consumers.

Mobile applications have proven its efficiency in increasing the brand equity through the appearance of brand awareness. Results of study indicated that employing mobile applications within the marketing process can help in increasing the awareness of the brand given that the application helps in fixing the brand in the memory of the client leading to higher equity. This idea argued before by Keller (2009) who states that employing mobile marketing can help in generating sales which in its turn can work on the level of awareness. Individuals who have the application and are aware of its usability and speed can also regenerate the brand as it is more stuck to their memory.

When it comes to loyalty, marketing through mobile (mobile marketing) also proved its efficiency in increasing customers' loyalty. For example, tourism and hotel booking applications are proved to be the most efficient in that domain. Many customers are - according to Kim (2011) - present more loyalty to a certain brand when engaging in its application through the web. The use of mobile application in that sense has saved customers time and effort which managed to be welcomed by customers and users.

As for brand loyalty, Kim and Alder (2011) argued that an organization's brand is basically the core of the organization. A brand establishes a name, a logo, an image, and personality. Making the items effortlessly open, offering comfort through helpful applications, and building brand awareness ought to be fused into the advertising 


\section{ENTREPRENEURSHIP AND SUSTAINABILITY ISSUES}

ISSN 2345-0282 (online) http://jssidoi.org/jesi/

2020 Volume 8 Number 2 (December)

http://doi.org/10.9770/jesi.2020.8.2(19)

methodology of each organization. Employing mobile applications can offer this and get the customers required with the brand using cell phone applications. Loyalty must begin with the collaboration of the item to the client. As the client turns out to be more aware of the item, the brand's equity develops. The positive, developing picture gives the brand a higher shot of holding the client for future item buys. Another factor for mark faithfulness is the perceptual propensity.

On the other hand, Kaplan and Haenlein (2010) insisted that picking a brand that offers items that are commonplace and agreeable to the purchaser guarantees mark steadfastness. By offering applications that permit check in/out administration, reservations, area benefit at the speed and comfort of a cell phone, permits the neighborliness benefit organizations to manufacture a solid brand association. It has been conjectured that utilizing versatile inn applications will have a constructive outcome all through the brand mindfulness, client commitment and brand responsibility, which thusly decidedly impacts the brand dependability.

\section{Conclusion}

Current study aimed at examining the influence of mobile application marketing on brand equity and how can an organization develop its brand equity and its variables (Brand Awareness, Perceived Quality, Brand Association and Brand Loyalty) through the employing of mobile applications as a marketing tool.

Sample of the study consisted of (520) consumers from different malls, retail stores and commercial complexes in Jordan. A self-administered questionnaire was distributed on the sample in order to gather data.

From the above mentioned results, it can be seen that there is a positive relationship between mobile application marketing and brand equity development. The use of friendly, useful and easy application can help in increasing the brand equity through focusing on the main variables including brand awareness, perceived quality, brand association and brand loyalty. The nature and characteristics of the mobile application can either attract or alienate individuals from a certain brand; this can be attributed to the technological developments which have opened the gate for brands to try their chance to be popular and widely accepted. Nowadays, customers can help in building brand equity, it not the responsibility of the organization anymore. This is read through the literature which proves that there are many practices and activities within the internet that enable the customer to build a virtual experience of the brand without even trying it; this is called the Word of Mouth - WOM - through exchanging reviews, point $f$ vies and experiences about a certain brand; a customer may be able to form some sort of feeling towards it, those feelings might be either positive of negative.

Understanding the power of mobile application is connected to how smart the organizations are. Building an application that can match the taste of each and every individuals is not that easy. It needs a lot of analysis and understanding of customers, how they think, what motive them, and what influence their purchase decision. From that point, the role of building a strong customer relationship management CRM can't be denied, through a wellbuilt CRM and organization may be more eligible to understanding its customers and how to build a mobile application that can math their taste and push them towards behaving in a way that is for the benefit of the brand and its equity.

Based on the reached aim and the answering of the study question, the following is recommended:

1- Carry out a research that examines the influence of mobile applications on health care performance and how can health care services be eased out for patients who do not have the ability to move from place to another like seniors and handicapped.

2- Examine the influence of mobile applications on teenagers purchase power and how can such applications increase the impulsive behavior of buying among teenage individuals in families. 


\title{
ENTREPRENEURSHIP AND SUSTAINABILITY ISSUES
}

ISSN 2345-0282 (online) http://jssidoi.org/jesi/

2020 Volume 8 Number 2 (December)

http://doi.org/10.9770/jesi.2020.8.2(19)

\section{References}

\begin{abstract}
Andrews, L., Drennan, J., and Russell-Bennett, R., (2012). Linking perceived value of mobile marketing with the experiential consumption of mobile phones. European Journal of Marketing, 46, 357-386. https://dx.doi.org/10.1108/03090561211202512

Awan, A.G. and Rehman, A.U., (2014). Impact of custo mer satisfaction on brand loyalty: An empirical analysis of home appliances in $\begin{array}{lllll}\text { Pakistan. British of } & \text { Marketing } & \text { Studies, } & \text { 2(8), }\end{array}$ https://pdfs.semanticscholar.org/f26f/2bd91be5431cc88829716486e10875a63f00.pdf
\end{abstract}

Becker, M., and Arnold, J., (2010). Mobile marketing for dummies. Wiley Publishing, Inc.

https://scholar.google.com/scholar?q=Becker,+M.,+Arnold,+J.,+(2010).+Mobile+marketing+for+dummies.+Wiley+Publishing,+Inc.\&hl=e n\&as_sdt=0\&as_vis $=1 \&$ oi $=$ scholart

Chinomona, R., and Sandada, M., (2013). The influence of market related mobile activities on the acceptance of mobile marketing and consumer intention to purchase products promoted by SMS in South Africa. Journal of Applied Business Research, 29(6), 1897-1908. https://doi.org/10.19030/jabr.v29i6.8225

Djerv, S. and Malla, Z., (2012). A qualitative study of the drivers of brand preferences in the Swedish smartphone market. Uppsala University. http://www.diva-portal.org/smash/get/diva2:534392/fulltext02

Dushinski, K., (2009). The mobile marketing handbook. New Jersey: Information today http://books.infotoday.com/books/Mobile-Marketing-Handbook-2nd-edition.shtml

Farquhar, P. H. (1989). Managing brand equity. Journal of Marketing Research, 1, 24-33.

https://www.coursehero.com/file/p1cg05q/Farquhar-PH-1989-Managing-brand-equity-Marketing-Research-Vol-1-No-3-pp-24-33/

Florido-Benítez, L. and Martínez, B.D.A., (2015). The effects of mobile applications as a marketing tool in airport infrastructure and airlines. International Journal of Leisure and Tourism Marketing, 4(3-4), 222-240.

https://www.researchgate.net/profile/Lazaro Florido-

Benitez/publication/288038692_The_effects_of_mobile_applications_as_a_marketing_tool_in_airport_infrastructure_and_airlines/links/56 a6a12808aeded22e354411.pdf

Forsido, M.Z., (2012). Brand loyalty in Smartphone. Master Thesis. Uppsala University https://www.semanticscholar.org/paper/Brand-loyalty-in-Smartphone-Master-ThesisHohenthal/35ae3791f4c516b1cb81457b1d65fd9ab8f36c6

French, A. and Smith, G., (2013). Measuring brand association strength: a consumer based brand equity approach. European Journal of Marketing, 47(8), 1356-1367. https://doi.org/10.1108/03090561311324363

Gordon, B.S., James, J.D. and Yoshida, M., (2016). The development of brand association measures in multiple product categories: New findings and implications for goods and service brands. International Journal of Business Administration, 7(3), 140.

https://doi.org/10.5430/ijba.v7n3p140

Gunawardane, N., Munasinghe, A. and Dissanayake, D.M.R., (2016). Relationship between Perceived Brand Equity and Purchase Intention of Life Insurance Brands in Sri Lanka: A Concept Paper. International Journal of Business and Management Invention, 5(12), 106-111. https://pdfs.semanticscholar.org/11b4/20744e97b5f65561103b9eb71d4e12a0a0ce.pdf

Hashem, T. (2016). The Impact of Social Media on Customers' Image for Mobiles, Journal of Advances in Humanities and Social Sciences, 2(5), 269-277. https://doi.org/10.20474/jahss2.5.3

Hazlett, K., (2011). Mobile Marketing Finding Your Customers No Matter Where They Are, Journal of Consumer Marketing, 3 , 239 -240. https://doi.org/10.1108/07363761111127662 


\section{ENTREPRENEURSHIP AND SUSTAINABILITY ISSUES}

ISSN 2345-0282 (online) http://jssidoi.org/jesi/

2020 Volume 8 Number 2 (December)

http://doi.org/10.9770/jesi.2020.8.2(19)

Joshi, M., (2013). Understanding Innovation. Amity University, Lucknow Campus - Amity Business School, May 6, 2013. Joshi, Manoj, Understanding Innovation (May 6, 2013). http://dx.doi.org/10.2139/ssrn.2261050

Kaplan, A.M. and Haenlein, M., (2010). Users of the world, unite! The challenges and opportunities of Social Media. Business Horizons, 53(1), 59-68. http://dx.doi.org/10.1016/j.bushor.2009.09.003

Keller, K.L., (1993). Conceptualizing, measuring, and managing customer-based brand equity. The Journal of Marketing, 1-22. https://doi.org/10.1177/002224299305700101

Keller, K.L., (2009). Building strong brands in a modern marketing communications environment. Journal of Marketing Communications, 15(2-3), 139-155. https://doi.org/10.1080/13527260902757530

Kim, D. and Alder, H., (2011). Student's Use of Hotel Mobile Application: Their Effect on Brand Loyalty. Viitattu, 15 , p. 2017.

King, N.J. and Raja, V.T., (2012). Protecting the privacy and security of sensitive customer data in the cloud. Computer Law \& Security Review, 28(3), 308-319. https://doi.org/10.1016/j.clsr.2012.03.003

Lee, V., Schneider, H. and Schell, R., (2004.) Mobile applications: Architecture, design, and development. Prentice Hall PTR. https://doi.org/10.1108/10610420010356966

Low, G.S. and Lamb Jr, C.W., (2000). The measurement and dimensionality of brand associations. Journal of Product \& Brand Management, 9(6), 350-370. https://doi.org/10.1108/10610420010356966

Masika, C, (2013). The influence of mobile marketing on brand equity; A case study of Safaricom Limited. Unpublished MBA Project, University of Nairobi.

https://chss.uonbi.ac.ke/sites/default/files/chss/THE\%20INFLUENCE\%20OF\%20MOBILE\%20MARKETING\%20\%20\%20\%20ON\%20B RAND\%20EQUITY\%20AT\%20SAFARICOM\%20LIMITED\%20Final-1-1.pdf

Pavlovaite, U., and Griesiene, I,. (2019). Development of an Art Platform in Terms of Relationship Marketing: a Biennial Case. Transformations in Business \& Economics, 18, 2(47), 259-278.

Piaralal, S. and Mei, T.M., (2015). Determinants of Brand Equity in Private Healthcare Facilities in Klang Valley, Malaysia. American Journal of Economics, 5(2), 177-182. http://article.sapub.org/10.5923.c.economics.201501.21.html

Priyantha, N.B., Miu, A.K., Balakrishnan, H. and Teller, S., (2001, July). The cricket compass for context-aware mobile applications. In Proceedings of the 7th annual international conference on Mobile computing and networking (pp. 1-14). ACM. http://nms.lcs.mit.edu/papers/CricketCompass.pdf

Pullig, C., (2008). What is brand equity and what does the branding concept mean to you. Baylor University. Waco-Texas.

Rubin, J., Gordon, M.I., Nguyen, N. and Rinard, M., (2015). November. Covert communication in mobile applications (t). In Automated Software Engineering (ASE), 2015 30th IEEE/ACM International Conference (pp. 647-657). IEEE.

https://doi.org/10.1109/ASE.2015.66

Schierz, P.G., Schilke, O. and Wirtz, B.W., (2010). Understanding consumer acceptance of mobile payment services: An empirical analysis. Electronic Commerce Research and Applications, 9(3), 209-216. https://doi.org/10.1016/j.elerap.2009.07.005

Severi, E. and Ling, K.C., (2013). The mediating effects of brand association, brand loyalty, brand image and perceived quality on brand equity. Asian Social Science, 9(3) https://doi.org/10.5539/ass.v9n3p125

Simon, C.J. and Sullivan, M.W., (1993). The measurement and determinants of brand equity: A financial approach. Marketing Science, 12(1), 28-52. https://www.jstor.org/stable/183736

Smith, K., T., (2010). Digital Marketing Strategies that Millennials Find Appealing, Motivating, or Just Annoying. Journal of Strategic Marketing, 1-27. https://doi.org/10.1080/0965254X.2011.581383

Sprosen, S., (2014). The influence of branded mobile applications on consumers' perceptions of a brand: the importance of brand experience and engagement (Doctoral dissertation, Dublin Business School). 


\section{ENTREPRENEURSHIP AND SUSTAINABILITY ISSUES}

ISSN 2345-0282 (online) http://jssidoi.org/jesi/

2020 Volume 8 Number 2 (December)

http://doi.org/10.9770/jesi.2020.8.2(19)

https://esource.dbs.ie/bitstream/handle/10788/1819/ma_sprosen_s_2014.pdf?sequence=1\&isAllowed=y

Tanakinjal, G., H., Deans, K., R., and Gray, B., J., (2011). Intention to Adopt Mobile Marketing: An Exploratory Study in Labuan. Asian Journal of Business Research, 1(1), 9-21.

https://www.academia.edu/1866689/Intention_to_Adopt_Mobile_Marketing_An_Exploratory_Study_in_Labuan_Malaysia

Tetere, M., (2011). Mobile marketing: brand performance and implications on brand identity: a case study of Adidas, Nike and Puma. Aarhus School of Business and Social Sciences, MA in Corporate Communication.

https://www.academia.edu/28642498/MOBILE_MARKETING_BRAND_PERFORMANCE_AND_IMPLICATIONS_ON_BRAND_IDE NTITY_A_CASE_STUDY_OF_ADIDAS_NIKE_AND_PUMA_Marta_Tetere_Exam_number_402939_MA_in_Corporate_Communicati $\underline{\text { on }}$

TrilloTrillo, A., (2017). Measuring Brand Equity in the Smartphone industry: An approach through Aaker's Model. https://ruc.udc.es/dspace/bitstream/handle/2183/19763/TrilloTrillo_Adrian_TFG_2017.pdf?sequence=2

Vikström, H. and Zheng, C., (2013). Branding through mobile applications:-A case study of Swedish campaign applications. https://pdfs.semanticscholar.org/a550/5c3f88dd964463b4b5a82ae47d80ac5d2fed.pdf

Washburn, B., (2011). Library mobile applications: What counts as success?. Information Outlook, 15(1), 13-15. http://www.oclc.org/research/publications/library/2011/washburn-io.pdf

Wood, L., (2000). Brands and brand equity: definition and management. Management Decision,38(9), 662-669. https://doi.org/10.1108/00251740010379100

Mohammad Fahmi AL-ZYOUD is an Associate Professor of the Marketing Departement, Business School at Al-Ahlyyia Amman University, Amman - Jordan.

Research interests: Branding, Social Media Marketing, Advertising, CRM, Global Marketing, e Marketing, Marketing Communaction, Marketing Strategy.

ORCID ID: https://orcid.org/0000-0003-2464-8162

Make your research more visible, join the Twitter account of ENTREPRENEURSHIP AND SUSTAINABILITY ISSUES: @Entrepr69728810

Copyright (C) 2020 by author(s) and VsI Entrepreneurship and Sustainability Center This work is licensed under the Creative Commons Attribution International License (CC BY). http://creativecommons.org/licenses/by/4.0/

(c) (i) Open Access 